\title{
Administrative and Court Reform in Central and Eastern Europe
}

\author{
Frank Emmert*
}

\begin{abstract}
The pre-accession programmes of the European Union and the candidate countries have focused heavily on law reform. Only relatively recently, it was recognised that successful administrative and court reform would be just as necessary in order to achieve the desired goals, namely that the candidates would eventually be able to take on their obligations as new members of the Union. Unfortunately, it has now become evident that it is easier to write new laws than to get them properly applied in every day practice. This article describes a number of cases to illustrate the problem. It shows that administrators and judges in Central and Eastern Europe have significant difficulties with Western working methods, specifically the application of international norms in the national legal order, due process and procedural safeguards, treatment of precedents, resolution of ambiguities and lacunae in the law, etc., which may in turn result in unjust and sometimes absurd application of laws. These difficulties cannot be resolved merely by organising ever more training courses and other theoretical programmes. The author claims that the majority of efforts promoting administrative and court reform applied so far have rendered only meager results. Therefore, additional and more creative measures have to be designed and implemented and have to be continued for years beyond accession of most of these countries to the EU in 2004. Otherwise, rule of law deserving its name will not materialise in the new Member States. The author concludes by offering some ideas based on many years of experience in the region.
\end{abstract}

\section{Introduction}

Binding EU ${ }^{1}$ law does not contain detailed rules or criteria to be fulfilled for a country to become a member of the Union. Article 6 (1) TEU merely refers to 'the principles of liberty, democracy, respect for human rights and fundamental freedoms, and the rule of law', which have to be respected by all candidates pursuant to Article 49 (1) TEU. Some additional criteria can be gleaned from other provisions in the treaties ${ }^{2}$ but much

\footnotetext{
* Professor of Law and Director of the Center for International and Comparative Law, Indiana University School of Law, Indianapolis, former Dean of the Law School, Concordia International University Estonia. This paper is a synthesis of ten years of experience of working with university students, practising attorneys, judges, public prosecutors and civil servants in the Czech Republic, Estonia, Hungary, Latvia, Lithuania, Poland, Romania, Slovakia, and Slovenia. The essence of the analysis, problems, and suggested solutions, applies to all of these countries. However, there are obviously differences in detail and the development has been uneven yet dynamic throughout. This should be kept in mind whenever a particular problem does not seem to be of concern in one country or a particular solution does not seem to fit in another.

1 Although this is not technically precise, 'European Union' will be used throughout this article, rather than 'European Community'. The author shares a growing perception in academic circles that the two organisations overlap sufficiently that their distinction can now be limited to cases where it actually makes a difference e.g. with respect to decision-making procedures.

${ }^{2}$ Such as the need to accept an 'open market economy with free competition' pursuant to Article 4 (1) EC
} 
is left open. ${ }^{3}$ This can be a problem both for potential candidates, if their administrative and/or economic structures are unfit for participation in the institutional framework and internal market of the EU, and for the EU itself, if it integrates markets in which its own goods, persons, and services are not protected adequately and from which problematic goods, persons, or services might originate. ${ }^{4}$ The very success of the European integration model depends on mutual trust and confidence that each partner will respect the law - not only in form but also in substance and play by the rules. ${ }^{5}$

Thus, as early as 1993, the conditions for accession were fleshed out at the Copenhagen Council, and 'the candidate's ability to take on the obligations of membership' was added. A formal 'pre-accession strategy' was launched at the Essen Council in December 1994. This led to the 1995 Commission White Paper on the Preparation of the Associated Countries of Central and Eastern Europe for Integration into the Internal Market of the Union. ${ }^{6}$ Although the White Paper mainly consisted of a list of all essential legislative measures to be adopted by the candidate countries in order to implement fully the acquis communautaire - i.e. the body of EU law as it stood at the timethe Commission also stressed that merely formal transposition of the legal rules was not sufficient and that suitable structures had to be created to ensure the application and enforcement of the new legal rules in practice?

Since 1995, the candidate countries have made great progress in the adoption of the necessary legislation for the implementation of the acquis communautaire. Many of the new laws are already in force, ${ }^{8}$ others have been adopted and would enter into force

${ }^{3}$ A good, if somewhat outdated overview is provided by Phedon Nicolaides and Sylvia Raja Boean, $A$ Guide to the Enlargement of the European Union: Determinants, Process, Timing, Negotiations (Maastricht, 1997).

${ }^{4}$ See SIGMA (ed.), 'Preparing Public Administrations for the European Administrative Space', Working Paper no. 23, (Paris, 1998); as well as SIGMA (ed.), 'Sustainable Institutions for European Membership', Working Paper no. 26, (Paris, 1998). See also European Commission, Making a Success of EnlargementStrategy Paper and Report on the Progress Towards Accession by Each of the Candidate Countries, (Brussels, 13 November 2001). This 'Strategy Paper' identifies four main reasons why the candidate countries have to create adequate administrative capacities: 1) to ensure the 'smooth functioning of the internal market' (which requires appropriate and effective regulatory authorities); 2) to provide 'sustainable living conditions in the European Union' (which requires the observation of environmental standards and adequate levels of health and safety, as well as inspection arrangements); 3) the 'overall protection of the European Union's citizens' (which requires secure borders, market surveillance for consumer protection purposes, adequate levels of food safety, and cooperation in justice and home affairs, as well as inspection and enforcement arrangements); and 4) the 'proper management of Community funds' (which requires appropriate structures for public procurement, financial control, audits, as well as mechanisms against fraud and corruption); all at 23.

${ }^{5}$ Big differences in administrative capacities in a Union of $25+$ would obviously be a problem; see A. J. G. Verheijen, 'Administrative Capacity Development-A Race Against Time?', WRR Scientific Council for Government Policy, Working Document W107, (The Hague, 2000), at 8. See also Deirdre M. Curtin and R. H. van Ooik, 'Revamping the European Union's Enforcement Systems with a View to Eastern Enlargement', WRR Scientific Council for Government Policy, Working Document W110, (The Hague, 2000).

${ }^{6}$ Com (95) 163 final of 3 May 1995. See also Marc-André Gaudissart and Adinda Sinnaeve, 'The Role of the White Paper in the Preparation of the Eastern Enlargement', in Marc Maresceau (ed.), Enlarging the European Union-Relations Between the EU and Central and Eastern Europe, (London, 1997), at 41-71.

7 This was endorsed by the Madrid Council in December 1995 and further developed by the Göteborg Council in June 1999, as well as the Feira Council in June 2000. See also Peter-Christian Müller-Graff, Die rechtliche Dimension der Osterweiterung der Europäischen Union', ECSA World Working Paper, (Brussels, 2000). Müller-Graff advocates 'inhaltliche und funktionelle Normrezeption', at 6 et seq. (emphasis added).

${ }^{8}$ For example, in the field of competition, most of the candidate countries have adopted national competition laws that are not only modeled on Articles 81 and 82 and the respective secondary legislation but that are in fact translations of the EU provisions. 
upon membership. Only a few remain to be adopted by the respective parliaments and for some of these, transitional periods have been negotiated so that their application can be delayed for some time beyond accession. ${ }^{9}$ Consequently, the 'track record' of the candidate countries with respect to the adoption of the necessary legislation has been relatively good and in the vast majority of cases the new laws do in fact correspond to the requirements set out by the respective EU rules.

However, while the number of newly adopted legislative acts can easily be verified, and while their content can be relatively easily compared to the EU rules to check whether they do in fact correspond, it is far more difficult to assess whether these new laws are properly applied in practice. For such an assessment, the Commission cannot rely on statistics or even self-evaluation reports from the candidate countries. Even quantitative data on administrative and judicial capacity (e.g. data on the number of judges, the formal qualification of attorneys, the money spent on re-training of civil servants), can not tell what is really happening when a citizen is injured by a defective product or discriminated against in the workplace; when a citizen applies for a licence or appeals an administrative decision; or when principles of due process are violated by an administrative or court authority. ${ }^{10}$ For a proper qualitative assessment of the administration of justice in a given country, one would have to make a detailed study of a representative cross-section of cases, covering attitudes in different parts of the population, advice given by attorneys, procedures before various administrative authorities, as well as judicial and extra-judicial dispute settlement and subsequent enforcement. While such a study could shed light on the landscape of administrative and court practice, it would seem prohibitively expensive and time-consuming. Consequently, this landscape is largely in darkness and the Commission is riding through it with dim headlights. ${ }^{11}$ Only the occasional lightning of a scandalous case that gets media attention gives us an idea of the kind of landscape that is really out there. And those glimpses have often been truly scary. ${ }^{12}$

As can be seen from the annual progress reports, ${ }^{13}$ the Commission has long recognised that administrative and court reform has been lagging behind parliamentary efforts at the implementation of the acquis communautaire in all CEECs. The language concerning the need to increase and improve efforts in administrative and court reform has become more and more pressing. ${ }^{14}$ However, until recently, the Commission has

9 For a complete overview of all transition periods that have been granted to candidate countries so far see http://europa.eu.int/comm/enlargement/negotiations/chapters/index.htm, accessed on 28 April 2003.

${ }^{10}$ As Carothers observed, 'foreign aid evaluations tend to focus more on outputs than on effects. That is, they tend to look at what activities the project sponsored, how many people were trained, what equipment was donated, how many consultant-days were used, and so forth, instead of assessing the real impact of aid, for example, whether civil servants performed better, decisionmaking became more transparent, local democracy developed, and so on'; see Thomas Carothers, 'Aiding Democracy Abroad: The Learning Curve', Carnegie Endowment for International Peace, (Washington, 1999).

11 Nevertheless, the Commission will have to give its evaluation on the readiness of each of the candidate countries on the basis of the 2002 progress reports, which were finalised in June 2002 by the Commission Delegations in the respective countries and were published in October 2002.

${ }^{12}$ Some recent examples will be given below at II.

13 These reports are available at http://europa.eu.int/comm/enlargement/report2002/ report 2002 accessed on 28 April 2003.

${ }^{14}$ Similarly, the Laeken Council in December 2001 emphasised that the negotiations on the different chapters of the acquis 'must go hand in hand with incorporating the acquis into legislation and actually implementing and enforcing it'. (here quoted from Com (2002) 256 final, at 2, emphasis added). 
not exactly offered much by way of guidance on how this reform should be conducted in a more effective way. ${ }^{15}$ Thus, it would not be realistic to expect fundamental changes between now and accession in 2004 in the administrative and judicial capacity of the CEECs. ${ }^{16}$ Progress will continue but it will be, as Max Weber has put it, 'a strong and slow boring of hard boards', which 'takes both passion and perspective'. ${ }^{17}$

This article will first present a number of real-life cases in order to demonstrate that successful - and rapid - administrative and court reform is in the best interest of the CEECs - regardless and independent of their accession to the EU. Second, there will be a discussion of the goals of administrative and court reform and of some of the practical hurdles to be overcome. Finally, various means of administrative and court reform will be analysed in order to show which of them are more and which less likely to contribute to the overall goals.

\section{The Need for Administrative and Court Reform}

In order to demonstrate that administrative and court reform with the goal of implementing Western (European) standards is in the best interest of all CEECs, even those that do not want to or cannot apply for membership in the EU, one only has to remember what an unreformed system looks like. The fact that the following examples are mostly from Estonia is only due to the professional affiliation of the author when writing this paper. ${ }^{18}$ The problems in other CEECs are similar, if not worse.

\section{A Methodological Problems with the Application of Human Rights and Fundamental Freedoms as Incorporated in National Constitutions and International Conventions}

The first example concerns the case of Tammer, an Estonian journalist, who was convicted of libel. Mr Tammer had interviewed Mr Russak, the author of a biography of Ms Laanaru. The latter had been the assistant of Edgar Savisaar, the most controversial Estonian politician and current mayor of Tallinn. Although married, Savisaar had an affair with Laanaru, which became known when she gave birth to his child. Subsequently, his marriage broke up and she gave the child away to be raised by her parents, as she was unwilling to give up her career. Against this background, Tammer asked

15 The latest effort in giving such guidance is the Communication from the Commission on the Action Plan for Administrative and Judicial Capacity, and the Monitoring of Commitments Made by the Negotiating Countries in the Accession Negotiations, Com (2002) 256 final, of 5 June 2002. This is a follow-up to the country-specific Action Plans for Reinforcing Negotiating Countries' Administrative and Judicial Capacity, which were first developed in the Communication from the Commission, Making a Success of Enlargement-Strategy Paper and Report on the Progress Towards Accession by each of the Candidate Countries, of 13 November 2001. The specific measures supported under these programmes will be discussed below at $\mathrm{V}$.

${ }^{16}$ This rather sceptical view is shared, e.g., by A. J. G. Verheijen, 'Administrative Capacity DevelopmentA Race Against Time?', WRR Scientific Council for Government Policy, Working Document W107, (The Hague, 2000), in particular at 24 et seq.

${ }^{17}$ Max Weber, Politics as a Vocation, here quoted from H. H. Gerth and C. Wright Mills (eds), From Max Weber: Essays in Sociology, (Oxford, 1946), at 128.

${ }^{18}$ For additional background information see also Jorma Heinonen and Frank Emmert, 'Challenges to Estonian Economic Development Provided by the Forthcoming EU Membership', in Kari Liuhto (ed.), Ten Years of Economic Transformation, Vol. I, The Economies in Transition and the EU Enlargement, (Lappeenranta, 2001), at 342-371. 
Russak: 'By the way, don't you feel that you have made a hero out of the wrong person? A person breaking up another's marriage (abielulöhkuja), an unfit and careless mother deserting her child (rongaema). It does not seem to be the best example for young girls'. ${ }^{19}$

When Laanaru pressed libel charges against Tammer, he was convicted under Article 130 of the Estonian Criminal Code of the offence of insulting Ms Laanaru and fined the equivalent of ten daily minimum income rates. The Estonian courts held that Tammer was justified in saying that Laanaru had broken up another's marriage and was neglecting her child. However, as he had gone beyond the mere statement of facts and had added a value judgement, he had crossed the border and insulted Ms Laanaru. The Estonian courts further held that Laanaru was not a public figure (in which case more critical press coverage might have been acceptable), even though she was by then the wife of Savisaar and had been at the centre of one of the biggest political scandals in recent Estonian history, taking full responsibility for Savisaar's secret tape recordings of conversations with other politicians. In the opinion of the present author, if these are to be the standards for the press in Estonia, then the very notion of 'freedom of the press' is led ad absurdum. Unfortunately, Tammer's conviction was upheld all the way to Strasbourg. The European Court of Human Rights failed to see the significance of the case for the freedom of the press in Estonia. It held that Estonia had not exceeded its margin of appreciation in deciding that Laanaru was not a public figure and had not imposed a disproportionate fine. ${ }^{20}$

This case shows that even supreme courts in CEECs cannot be trusted for the proper application of human rights and fundamental freedoms in the context of ordinary civil, administrative or criminal cases. The judgement of the Estonian Supreme Court satisfied in form by discussing some of the cases of the European Court of Human Rights. But it failed in substance. It gave neither individual justice to $\mathrm{Mr}$ Tammer, nor any clear guidelines for future similar situations. Last but not least, the European Court-with its already huge backlog, and without a more qualified argumentation on behalf of Tammer - fell into a trap: swayed by the formal discussion in the national judgement and the apparently small fine, it decided not to dig any deeper.

\section{B Methodological Problems with Due Process and Other Procedural Rights}

In March 2001, the new law on bailiffs entered into force in Estonia. On the one hand, this new law brought important changes to the institution of the bailiff by privatising a formerly public function. On the other hand, it did not provide sufficiently detailed rules on how the bailiffs have to go about their business. One of the functions of the bailiffs is to enforce financial penalties in cases of administrative offences. If the accused does not pay the fine after notification by the administration, the matter is handed over to the bailiff. The latter is obliged to notify the accused (again) and warn him or her of enforcement measures. If the fine is still not paid, the bailiff has the possibility of seizing assets of the accused in order to enforce the fine plus a fee for his or her own

19 This translation is taken from the judgement of the European Court of Human Rights in the case of Tammer $v$ Estonia (Application no. 41205/98), of 6 February 2001, Rec. 22. The Estonian terms 'abielulohkuja' and 'rongaema' do not have direct translations in English. In German, the equivalents would be 'Ehebrecherin' and 'Rabenmutter', which are certainly not grossly defamatory or degrading terms.

20 Apparently, the European Court also failed to see the problem that Mr Tammer could be punished more severely as a repeat offender in future cases of alleged libel. 
services. So far, this is standard procedure, common in many countries. However, the rules of procedure for the bailiffs are not specific enough and invite abuse. In particular, it is not specified how the bailiff has to notify the accused of the alleged offence. A widely known problem will demonstrate what happens when state authority is transferred to private, profit-seeking institutions without sufficiently clear rules of conduct and without proper supervision. ${ }^{21}$ A large number of Estonian drivers have seen sums of up to $€ 75$ taken from their bank accounts in recent months. Those who made inquiries with the bank were informed that one or the other bailiff had ordered the transfer for an unpaid parking ticket. Those who inquired with the respective bailiff were informed of the date of the alleged offence, which may have been as far back as 1999 , when a general prohibition of unpaid parking in the centre of Tallinn was introduced. Supposedly, the offenders should have received a notification from the police on their windshields. Later, if they did not pay, they should have received a letter from the bailiff. If they still did not pay, they should have seen a public announcement in the newspapers. And only after having ignored even that, should the bailiff have taken the money from their bank accounts. Again, this sounds good in theory. However, in practice it is quite common for drivers to take parking tickets from the windshields of other cars in order to create the impression for subsequent police patrols that their car is already taken care of. Thus, the original offender may well not receive the police notice. As far as written notification by the bailiff is concerned, this does not have to be by registered mail. Even though a simple violation of the parking rules, for example by exceeding the pre-paid time by just a few minutes, is punishable by a fine of about $€ 40$ - very high given the relatively low average income in Estonia - the bailiffs claim that it would be too expensive to send even one registered letter to each offender. Interestingly, the non-registered mail seems to get lost in literally thousands of cases. That leaves the public announcement in the newspapers as the main source of information for the accused. However, this is organised in such a way that it is made as difficult as possible for a person to find his or her name. First of all, nobody will know when to expect such an announcement and will, thus, not look for it. Second, the publication of hundreds of names covers a whole page in what must be about point size 4 and is not in alphabetical order. Consequently, the chances of an accused finding out about the alleged offence and defend themselves or pay the original fine are marginal at best. And this is exactly what the bailiffs are interested in, since they can add about $50 \%$ to the fine if they have to take it from the offender's bank account. Although there is an obvious conflict of interest for the bailiffs between adherence to standards of due process and personal gain, it is not very inviting for the victims to start court procedures for repayment of their money. ${ }^{22}$ First of all, the individual sums are relatively small. Second, the accused will never be able to prove that the bailiff did not in fact send a letter of notification and that they did not in fact receive the ticket from the police. Last but not least, given the very long time between the alleged violation of the

${ }^{21}$ Supervision is in the hands of the Ministry of Justice, which has in fact started criminal proceedings against more than 15 out of 77 Estonian bailiffs since the change of the law in 2001. See Ilona Urb, The Reformed Institution of Bailiffs in Estonia and the Position of a Bailiff in the System of Public Administration (Tallinn, 2002), unpublished thesis, available in the library of Concordia International University Estonia, and interview on 28 June 2002 with Angelika Järg, in charge of supervision of the bailiffs at the Estonian Ministry of Justice.

${ }^{22}$ Nevertheless, a number of cases are now pending before Estonian courts and may eventually go to Strasbourg. (Several names and other data are on file with the author.) 
parking rules and the taking of the money, they would hardly be able to prove that they may not even have been in town with their car on the day in question. ${ }^{23}$

Another case is reported from Romania, but in fact is not untypical of other CEECs. It concerns the performance of court-appointed defence counsels. In concreto, there was a hearing in Pitesti court (some $100 \mathrm{~km}$ from Bucharest) in December 1997 regarding three separate applications for release in pre-trial detention cases. In all three cases, the only thing the court-appointed counsels could say on behalf of their clients was 'I leave the decision to the court' ${ }^{24}$ Cases where a court-appointed defence counsel has not read the files or is otherwise ill-prepared are not unknown in the West. However, in CEECs there are additional systemic problems. The profession of attorney is very lucrative in countries such as Estonia, with partners of bigger law-firms billing up to $€ 250$ an hour, almost equivalent to the monthly wages of a nurse or school teacher. By contrast, the compensation paid by the government for services of a court-appointed counsel is only about $€ 12$ an hour. As a result, these kinds of cases are not exactly popular among the attorneys. Since the bar association is nevertheless required by law to provide counsel for cases where legal aid is granted by the courts, it has introduced a rule according to which trainee lawyers must take at least 25 such cases before they can take the bar exam. ${ }^{25}$ This solution obviously suits the members of the bar just fine. Whether it is also suitable for the recipients of legal aid is another question. ${ }^{26}$

Both of these examples show that procedural guarantees, which are considered on virtually an equal footing with fundamental human rights and freedoms in the West, do not enjoy similar respect in Central and Eastern Europe. In addition, it is simply not part of the legal culture for a victim of improper or even illegal behaviour by state officials to complain to their superiors or the courts. ${ }^{27}$ Thus, the process of change is slow at best.

\section{Methodological Problems with Ambiguities and Lacunae in the Law}

At the present time, there are a lot of problems with the application of new laws by the administrative and court authorities in CEECs. As is well-known, the transition

${ }^{23}$ A young Estonian lawyer recently reported another example: his client had some $€ 250$ taken from his bank account. When he inquired, he was told that this was the fine for the night when he had been apprehended completely drunk by the police and had been held in custody to sober up. However, the client had never been in such a situation. Somebody else must have given his name. Since then, the lawyer had been to court on numerous occasions but the arresting police officer consistently failed to show up, claiming urgent official business. The outcome is almost predictable. Either the client will give up in frustration or the procedure will take so much time that the police officer will be able to claim that he cannot possibly say whether or not this is the right man. (The names and other data are on file with the author.)

${ }^{24}$ See Monica Macovei, 'Citizen and Law After Communism-Legal Culture in Romania', (1998) 7 East European Constitutional Review, 1, here quoted from http://www.law.nyu.edu/eecr/vol7num $1 /$ feature/legalculture.html, last accessed on 22 June 2002. A number of similar incidents are reported in 'Latvia's Shaky Scales of Justice', (2000) Central Europe Review, 18 September.

${ }^{25}$ Statutes of the Estonian Bar Association; and interview on 20 June 2002 with Alice Salumets, attorney with Alvini \& Partners, Tallinn.

${ }^{26}$ The availability and quality of legal aid and access to justice is currently subject of a comparative study organised by the Polish National Access to Justice Forum. The report on Estonia was written by the present author together with Anne Adamson and is in print (as of April 2003).

${ }^{27}$ On the mechanisms that are being used in CEECs in the relationships between citizens and state institutions, businesses with each other, economic actors with the state, and non-profit organisations with other actors, see Susan Rose-Ackerman, 'Trust and Honesty in Post-Socialist Societies', (2001) $54 \mathrm{Kyklos}$, at $415-444$. 
from Soviet-style planned economies to democratic market economies requires the adoption of many new laws and changes to virtually all the rest. Preparation for membership in the EU and the need to bring the candidate countries' legal systems rapidly up to the level achieved over decades by the old Member States also translates into a veritable avalanche of new legislation.

However, the problem with the application of the law by the courts and administrations is by no means limited to the new laws that have to be learned. There are additional methodological weaknesses that are part of the communist heritage. This can be illustrated by the famous Vichmann case. Mr Vichmann was an executive with Hoiupank, a medium-sized Estonian bank. During takeover negotiations with Hansapank, the largest Estonian bank, Vichmann made a series of securities transactions on behalf of Hoiupank and credited the proceeds, some US\$13 m, to an account to which only he had access. When Hansapank found out about the transactions and where the money had gone, it accused Vichmann of embezzlement and demanded repayment of the money. To general surprise, the public prosecutor refused to bring charges, arguing that he saw no evidence for criminal intent. To even greater surprise, Vichmann defeated the civil claims of Hansapank not only at first instance but also on appeal, and even before the Estonian Supreme Court. On the basis that the judges could not find any rules that Vichmann had breached, they rejected the claims for reimbursement, respectively damages by the bank, and Vichmann got to keep the money. ${ }^{28}$

The case illustrates a number of methodological problems that are widespread in Central and Eastern Europe. First of all, the judges are trained to apply the law and the (written) law only. They have no training to overcome lacunae in the law, for example, by recourse to general principles of law, such as the notion of unjust enrichment. Second, the judges have no experience with the concept of justice in contrast to the concept of law. This can lead to cases where the letter of the law is duly followed but the result is obviously unjust, if not outright absurd.

A particular problem can be identified with the treatment of precedents. In recent litigation before an Estonian court of first instance, the author was advised by cocounsel not to make reference in the written brief to established case law, because the judges might react adversely to such an attempt at questioning or restricting their judicial independence. Subsequent research showed a widespread misunderstanding of judicial independence in CEECs. ${ }^{29}$ When a reference to case law is made, the judges in this part of the world tend to reply that their system is not like the American system of stare decisis. As a result, they refuse even so much as to look at precedents, regardless of whether they are decisions from their appellate courts, or even their supreme court, let alone a different chamber of their own court. ${ }^{30}$ This sometimes produces almost comic results, with courts continuing to apply legislation in full knowledge of a decision by their supreme court declaring that very legislation unconstitutional (until it is formally repealed by their parliament) - or where different judges of the same court decide virtually identical cases differently without so much as a word of explanation. What many judges - and for that matter, the majority of all lawyers in CEECs, across legal professions - do not understand is the proper methodological treatment of

\footnotetext{
${ }^{28}$ See also Frank Emmert, 'The Independence of Judges - A Concept Often Misunderstood in Central and Eastern Europe', (2001) 3 European Journal of Law Reform, 4, at 405-409.

29 Ibid.

${ }^{30}$ As a side-effect, case law is still not widely reported or publicly available at all in many CEECs.
} 
precedents in continental European legal systems. ${ }^{31}$ What they do not understand is that while they are-obviously - not formally bound to follow a precedent, they jeopardise their legitimacy if they do not explain why they decide a case differently from an analogous earlier case. Furthermore, they miss important opportunities to develop their legal system, to provide guidelines on the proper interpretation of ambiguous legal rules and to fill lacunae in the law. The result is a system in which judges are taking pride in their maximum judicial independence ${ }^{32}$ and failing to understand their accountability to society. ${ }^{33}$ Hence, their work is widely perceived as 'too independent', that is, arbitrary, by that society.

\section{$D$ Problems with Soviet-Style Thinking: Authoritarianism, Nepotism, Pork-Belly Politics, Corruption, Indecision...}

All over Central and Eastern Europe there is a multitude of examples of citizens being harassed by the authorities, pressed to pay bribes, denied their rights to obtain permits or licences, or otherwise injured in their fundamental rights and freedoms; and yet, they do not complain, and for sure, they do not call upon the courts. ${ }^{34}$ If they do, they may

31 At a recent meeting in Helsinki, several Finnish law professors reported about a conference at the University of Tartu, the leading law school in Estonia. They were full of praise for the friendly reception and general level of the conference. Yet, they also remarked that at least some of their Estonian counterparts obviously lacked Western-style professional skills of legal argumentation.

${ }^{32}$ For a detailed comparative study of judicial independence in CEECs see Open Society Institute (ed.), Monitoring the EU Accession Process: Judicial Independence (Budapest, 2001). This study contains an excellent general chapter on judicial independence in the context of EU accession, as well as country reports for Bulgaria, the Czech Republic, Estonia, Hungary, Latvia, Lithuania, Poland, Slovakia, and Slovenia. The findings differ considerably but are generally rather critical. The study on Estonia was criticised as too critical even by the Commission Delegation in Tallinn. However, in the opinion of the present author, the study puts the finger exactly on the soft spots and should be complemented for a neutral and thorough analysis without any political or other deference. Only if the yardstick of Soviet-style dependence is applied - i.e. the former subordination to the government and the Communist Party-do most CEEC judiciaries look relatively good. See also USAID Office of Democracy and Governance, Guidance for Promoting Judicial Independence and Impartiality (Washington, 2001), in particular at 53 et seq. For examples from the Ukraine, where little has changed so far, see Maureen B. Fitzmahan, "Vestiges of Soviet Control Mechanisms in the District Court of Ukraine', (2000) 7 Columbia University Journal of East European Law, 2, at 341-390, in particular 381 et seq. Fitzmahan describes, inter alia, how judges would be summoned for reprimand or not re-appointed if they did not follow official guidelines of party policy, at footnote 37. A classical description of the procuracy and its virtual omnipotence in Soviet times can be found in Harold J. Berman, Justice in the USSR: An Interpretation of Soviet Law (1963). The more subtle modern methods of dealing with too independently minded judges in the Ukraine are described in United States Department of State, Bureau of Democracy, Human Rights, and Labor, Ukraine Country Report on Human Rights Practices for 1999, http://www.state.gov/g/drl/rls/hrrpt/1999/index.cfm?docid=367. The present author would like to thank Professor Fitzmahan for these sources and information.

33 Useful additional information on the status and functions of judges can be found in Amnesty International (ed.), Amnesty International Fair Trials Manual (1998), available at

http:/www.amnesty.org/ailib/intcam/fairtrial/fairtria.htm, last accessed 28 April 2003; General Council of the International Association of Judges (ed.), Universal Charter of the Judge, (Taipei, 1999); European Association of Judges (ed.), Judges' Charter in Europe, (1993); and Council of Europe (ed.), European Charter on the Status of Judges, (Strasbourg, 1998).

34 Macovei put it as follows: 'Many people still fear authority, and many officials, consciously or not, still behave like masters, or else they simply refuse to act out of an inherited fear of taking responsibility ... [T] he most basic elements of the law are not yet part of society's education, and most have not the slightest idea how to react to protect their rights if they find themselves on the spot, when stopped by a policeman, say, or when questioned by a state bureaucrat'. See Monica Macovei, 'Citizen and Law After 
find themselves in a maze of opaque and illogical procedural rules that they cannot possibly fulfil or where various parts of the authorities are covering for each other. ${ }^{35}$

In Latvia and Lithuania, it was, until very recently, customary for the police randomly to stop drivers and demand cash payment of hefty fines. ${ }^{36}$ If the drivers were foreigners, they were accused of something or other and threatened with the withdrawal of their licence or the confiscation of their vehicle. After sufficient intimidation, the police officers would then generously offer that the entire affair could be forgotten if the equivalent of $€ 100$ or so would be paid in cash without receipt. All foreigners who regularly travelled to these countries were aware of this practice and kept a small amount of local money - equivalent to maybe $€ 15$ or 20 - in a special wallet for police raids. Resort to the courts was generally considered useless, as the judges were suspected of getting their percentage of the revenue. In general, there are many holding public office who seem to be there only for (illegal) personal gain. One of the high-level examples is the former Latvian Prime Minister Andris Skele, who had to resign in 2000 in the middle of a scandal concerning a conflict of interest with his business holdings. In order to demonstrate that his political choices were independent of his commercial interests, Skele announced that he had sold his food-processing conglomerate, Ave Lat, for US\$29 $\mathrm{m}$. Later he was accused of having sold his business to an offshore company that he continued to control, and questions were raised concerning where a politician with a modest salary obtained a company of that value in the first place and whether his former position as a high-ranking official in the Ministry of Agriculture might have had something to do with it. ${ }^{37}$

The last example to be given here is the case of an Estonian businessman who imported a train-load of crude oil from Russia. Since there was a problem with the

Communism-Legal Culture in Romania', (1998) 7 East European Constitutional Review, 1, here quoted from http:/www.law.nyu.edu/eecr/vol7numl/feature/legalculture.html. See also the examples given by Alexandra Sviridova, 'Citizen and Law After Communism-Living in Lawlessness', (1998) 7 East European Constitutional Review, 1, here quoted from http://www.law.nyu.edu/cecr/vol7num1/feature/ livinglawless.html, accessed on 28 April 2003.

35 The Soviet-style court procedure, which has not changed much, at least in the CIS States, is analysed in detail by Maureen B. Fitzmahan, "Vestiges of Soviet Control Mechanisms in the District Court of Ukraine', (2000) 7 Columbia University Journal of East European Law, 2, at 341-390.

${ }^{36}$ One journalist who regularly went to visit his relatives for the weekend reported of the local policeman who was already waiting for him every Friday afternoon in a small town on the way. When protesting and claiming that he had not violated any traffic rules the police officer answered that he could take the car apart until he found something wrong with it and that it would be easier for both sides if the driver just paid.

37 For years, Latvian politics have been heavily influenced by two powerful politicians/businessmen, Andris Skele and Aivars Lembergs. The latter is the mayor of Ventspils, the main port of Latvia; at the same time he controls the state-owned Ventspils Oil conglomerate. For additional information see Central Europe Review (CER), "They're All Paid Off in Cash, Top Offices and Girls"-Has the ugly truth about Latvian politics been finally revealed?', 17 May 1999; CER, 'Stability Sacrificed', 17 April 2000; and CER, 'When Sweet Turns to Sour', 5 February 2001. For a scientific analysis of the privatisation of Latvia's food and food-processing industry see Danute Jasjko, Monitza Hartmann, Michael Kopsidis, Andris Miglaus and Jürgen Wandel, 'Restructuring the Latvian Food Industry: Problems and Perspectives', Discussion Paper No. 10, Institute of Agricultural Development in Central and Eastern Europe (Halle, 1998). On the problems related to the privatisation of vast state assets see also Robert Cull, Jana Matesova, and Mary Shirley, 'Ownership Structure and the Temptation to Loot: Evidence from Privatized Firms in the Czech Republic', World Bank Working Paper WPS 2568, (Washington, 2001). Finally, on the various forms of privatisation and the issue of restitution claims, see, e.g., Marie Lavigne, The Economics of Transition-From Socialist Economy to Market Economy, 2nd edn (London, 1999), in particular at 165 et seq 
customs documentation - a stamp was missing or in the wrong place - the oil was detained by Estonian customs and he was accused of attempted customs fraud. The businessman took the matter to the administrative court and obtained a ruling according to which he was not responsible for the mistake and was entitled to release of the oil. The customs authorities did not challenge this ruling and it became res judicata. However, in the meantime the customs authorities had sold the oil below its value and would have had to pay damages. Hence, they persuaded the public prosecutor to initiate criminal proceedings against the businessman for customs fraud. When the latter complained, he was threatened with imprisonment for obstruction of justice.

Since the businessman had to pay his Russian suppliers and had to pay damages for contracts he could no longer fulfil to his own customers, he went into bankruptcy. As part of the insolvency procedures various assets, including a number of valuable pieces of property, were sold by the court-appointed liquidator. Most of these were sold at ridiculously low prices, sometimes below the annual rental income. Formally, the sale was by auction. However, the auction was not public and was not even publicly announced, and that was precisely why the buildings and land did not attract higher bids. The reader may decide for herself whether the liquidator was totally incompetent or used the opportunity to sell the assets to his friends and share the profit.

For several years, all inquiries about the progress of the criminal case went unanswered. Only now, after more than five years and under the protection of the statute of limitations, has the businessman dared to initiate state liability proceedings for some $€ 3 \mathrm{~m}$ in damages. Considering the large amount of money at stake, his hopes of finding justice in Estonia are low. Whether he will have the financial means to take this case all the way to Strasbourg and whether he will be able to prove to the European Court of Human Rights that the damage was grossly and illegally exacerbated during the insolvency proceedings remains to be seen. ${ }^{38}$

Again, the examples show how various parts of the state administration are incompetent or corrupt in their proceedings and how difficult, if not impossible it is for the citizen to stand up against them. For many in the public administration, the state is still a self-service entity, as it was in Soviet times, where the game is to get the best result for one's self. The difference compared to previous times, however, is that now those corrupt and greedy administrators can actually own and publicly enjoy what they steal from the state and society as a whole, even if it takes a few tricks and maybe a few offshore companies to do so.

\section{The Goals of Administrative and Court Reform}

The above examples have shown the kind of legal environment that can often be found in the wake of the collapse of Communism in Central and Eastern Europe. The former rigorous and oppressive state authority, which at least had been able to guarantee personal safety and access for all to the basic means of human survival, has collapsed, and the future democratic authority, which will be governed by the rule of law, is still under construction. In the meantime, power is shared between reformed and democratic structures, still unreformed Soviet-style bureaucratic structures and mafia-like public and private structures. Which of these gains the upper hand in a given case depends on the country, the specific circumstances and a good deal of luck.

${ }_{38}$ The name and other data are on file with the author. 
This situation is not only unsatisfactory for the people having to live with it, who are deprived of fundamental human rights and freedoms time and again, and often experience inefficiency and arbitrariness when having to deal with the administrative and court authorities. It is also a major reason for potential foreign investors to tread cautiously in Central and Eastern Europe or even to stay away altogether. ${ }^{39}$

Against this background, it can safely be said that the CEECs are not going to develop their full economic potential, and are not going to be able to provide sustainable growth for the benefit of more than a small oligarchy (the capitalist version of the nomenclatura), ${ }^{40}$ unless there are fundamental changes in the administration and in the courts. Furthermore, the entire process of democratisation is at risk in countries where the population perceives one government after another as a self-serving band of crooks and the public administration as their tool in the accumulation of private gain, ${ }^{41}$ and where the rule of petty bureaucrats ${ }^{42}$ has replaced the rule of the Communist Party, refusing to give way to the rule of law.

Consequently, should it not be in the obvious self-interest of all CEECs to address these issues and to achieve real reform in the administration and in the courts regardless of EU membership? It is overly simplistic to aggregate self-interest in such a way. Realistically, one has to acknowledge the powerful vested interests in the status quo, of those who are using governmental or economic structures to promote their personal self-interest - and of those who at least occasionally manage to catch a few crumbs that fall from the table of the wealthy and powerful, in exchange for their loyal services. While these groups together are but a relatively small minority, they hold the keys to

39 For detailed analysis of the factors inhibiting development, see Saule Voluckyte, "Why is Lithuania Lagging Behind in Terms of Economic Development-A Legal Analysis', (Tallinn, 2002), unpublished thesis, available in the library of Concordia International University Estonia. On the basis of interviews with and surveys of foreign investors, Voluckyte identifies the following major factors restraining market-based business activities in Lithuania: the bureaucracy, in particular its inefficiency and its corruption; shortcomings in the legal environment, in particular the lack of predictability; the tax system; and the customs régime (in descending order of magnitude). A different view, however, is presented by John Hewko, who claims that '[an] extensive overhaul of a country's legislative and institutional framework is generally not a necessary precondition for the postcommunist countries of Eastern Europe and the former Soviet Union to attract direct investment ... A significantly more important factor for investors is the existence of genuine business opportunities'; see John Hewko, 'Foreign Direct Investment: Does the Rule of Law Matter?', (2002 Transition March-April, at 11-13. While this may be true for resource-rich countries like Azerbaijan, one should not forget that investors today can choose between more than 180 countries competing for their money and even in Central and Eastern Europe more than a dozen countries are in direct competition and have otherwise similar business opportunities to offer. For the present author, it would be foolish to deny that the legal culture plays a major role in investment decisions, in particular now, after privatisation opportunities are gone, and the countries compete for 'green-field investment'. See also David A. Grigorian and Albert Martinez, 'Industrial Growth and the Quality of Institutions: What do (Transition) Economies have to Gain from the Rule of Law?', World Bank Working Paper WPS 2475, (Washington, 2000); as well as OECD External Relations Division (ed.), Bureaucratic Barriers to Entry: Foreign Investment in Central and Eastern Europe (Paris, 1994). For comparative information on the legal systems of the three Baltic States, see Aku Sorainen, Theis Klauberg, Eva Berlaus, and Tomas Davidonis, A Foreign Investor in the Baltics (Helsinki, 2002).

${ }^{40}$ There is already a joke being told in CEECs, according to which in Communism man exploits man and in capitalism it is the other way around.

${ }^{41}$ After a series of corruption scandals, an opinion poll in Latvia showed that $75.9 \%$ of the respondents thought it impossible to get rich by honest means. See 'Stability Sacrificed', (2000) Central Europe Review, 17 April.

42 This expression was coined by Stephen Holmes, 'Citizen and Law After Communism-Introduction', (1998) 7 East European Constitutional Review, 1, here quoted from http://www.law.nyu.edu/eecr/vol7num1/feature/intro.html. 
the vast majority of resources in the CEECs. Furthermore, it should not be forgotten that a system of a small oligarchy or nomenclatura, protected and fed by a somewhat larger circle of loyal and dependent vassals, has a great tradition in Central and Eastern Europe and has supported such diverse power structures as the Tsarist aristocracy and the Communist Party. ${ }^{43}$

This is precisely where accession to the European Union can make all the difference. By promoting efficient, transparent, predictable and generally fair legislation, and by pushing for and supporting fundamental changes in the administration and courts, the EU is not only protecting itself against unsuitable new Member States. The accession perspective has become the most powerful catalyst for democratisation and Westernisation of the legal cultures of the candidate countries ${ }^{44}$ and, consequently, for the promotion of the best self-interest of their societies at large. ${ }^{45}$

When reflecting on the goals to be achieved in the process of administrative and court reform in order to achieve the tidal change from the old and still prevailing situation to genuine rule of law and justice, one can distinguish specific goals and meta-goals.

The most important meta-goals, which apply across sectors and for different institutions ${ }^{46}$ can be summarised as follows:

43 Verheijen identifies a number of factors that contribute to failure of reform processes:

- "administrative reform strategies are often designed "on the drawing board" without sufficient "testing" their feasibility or involving the main stake-holders in the process of the design;

- the value of legislation as a tool has been generally overestimated. Adopting (a) law(s) does not necessarily lead to changes in the operation of the administration. Law as a reform instrument only works if other conditions are fulfilled simultaneously;

- administrative development does not win votes, politicians therefore tend to lose interest, even if they subscribe in principle to the need of creating efficient, professional and reliable administrations;

- administrative reform programmes need to be pursued over a long period of time if they are to have significant results. Therefore administrative reform processes will generally fail under conditions of high turnover between governments, unless they are based on a broad consensus between political forces;

- the need to 'win over' civil servants, either by involving them from the start or by 'changing administrative culture' is a highly underestimated element of reform programmes;

- the transferability of administrative reform strategies is limited; approaches to reform that have been applied in other states are unlikely to lead to success, unless these are well-adapted to local conditions'.

See A. J. G. Verheijen, 'Administrative Capacity Development-A Race Against Time?', WRR Scientific Council for Government Policy, Working Document W107, (The Hague, 2000), at 39.

44 A very good analysis from a political science perspective is provided by Antoaneta Dimitrova, 'The Role of the EU in the Process of Democratic Transition and Consolidation in Central and Eastern Europe', in Office for Official Publications of the European Communities (ed.), The European Union in a Changing World, a selection of papers from the $3^{\text {rd }}$ ECSA-World conference (Brussels, 1998), at 315-337, with useful further references. See also Alain Guggenbühl, 'The Political Economy of Association with Eastern Europe', in Finn Laursen (ed.), The Political Economy of European Integration (The Hague, 1995), at 211-282; as well as Barbara Lippert, Gaby Umbach, and Wolfgang Wessels, 'Europeanization of CEE Executives: EU Membership Negotiations as a Shaping Power', (2001) 8 Journal of European Public Policy, Special Issue on Executive Governance in Central and Eastern Europe, 6, at 980-1012.

45 Anyone who agrees with this analysis will also share the present author's concern about those countries, like Russia, the Ukraine, Belarus, and others, which do not have an accession perspective and which do not benefit, therefore, from the catalytic effects of working more and more closely with the EU. Europe must absolutely avoid repeating the mistake made with Germany after World War I, this time with Russia.

${ }^{46}$ These goals can be called 'horizontal' and should be distinguished from the more specialised 'vertical' expertise within a given administrative unit. See WRR Scientific Council for Government Policy (ed.), Towards a Pan-European Union, Report no. 59, (The Hague, 2001) at p. 83, and Barbara Nunberg, 'Ready for Europe; Public Administration Reform and European Union Accession in Central and Eastern Europe', World Bank Technical Paper no. 466 (Washington, 2000). 
- governmental and administrative decisions must be taken in the best interest of society as a whole - the polity — rather than in the private interest of the decisiontakers, the interest of a self-serving bureaucracy, the interest of 'the State', or the interest of the EU;

- functioning control mechanisms must be established via checks and balances, i.e. a true division of power between the legislature, the executive and the courts, and a better comprehension of the specific tasks of each branch of the divided state authority;

- all three branches of government must learn to respect fundamental principles of law and the international obligations of their State when making, interpreting and applying the law;

- the laws and their application must become transparent and predictable;

- corruption must be brought down from African levels to Western levels; ${ }^{47}$

- meritocratic hiring and promotion systems must become the norm in the public sector;

- institutions must become 'strong' in a positive sense, characterised by efficiency, consistency and legitimacy. ${ }^{48}$

In order to achieve these cross-sectoral goals, certain specific goals can be formulated for each relevant group in society:

- politicians have to learn to respect the limits to their powers determined by their constitution, international and fundamental principles of law, and their system of checks and balances;

- judges and prosecutors have to learn to apply the letter and the spirit of their new and democratic laws and to be truly independent in their decisions;

- attorneys have to understand their important function in the legal culture and become subject to internal and external quality control mechanisms; they should seek to prevent conflicts and disputes, where possible; they have to provide high

47 According to the Commission, "corruption, fraud and economic crime remain widespread in many candidate countries, where they contribute to a lack of confidence by the citizens and discredit reforms'; see Communication from the Commission, Making a Success of Enlargement-Strategy Paper and Report on the Progress Towards Accession by each of the Candidate Countries, of 13 November 2001, at 10. The most comprehensive analysis of corruption is provided annually in the Corruption Perceptions Index of Transparency International. The most recent available survey of 28 August 2002 ranks 102 countries and is led by Finland, the country with the best score $(9.7$ out of 10 , where 10 stands for highly clean and 0 for highly corrupt). The best performer in Central and Eastern Europe was Slovenia with a score of 6.0, putting it in 27th place. Hungary and Estonia follow close behind in 29th and 33rd place respectively. For comparison, the poorest performers among the old Member States are Italy and Greece, in 31st and 44th place, with absolute values of 5.2 and 4.3 respectively. The Czech Republic, Latvia, and Slovakia share the 52nd place, and Romania can be found in 77 th place, with a score of 2.6 , behind even Russia and Zimbabwe. The average score of the ten candidate countries in Central and Eastern Europe is 4.27, whereas the average score of the 15 Member States is 7.55. See http://www.transparency.org/cpi/index.html cpi. See also Joel Hellman and Mark Schankerman, 'Intervention, Corruption and Capture-The Nexus Between Enterprises and the State', (2000) 8 Economics of Transition, 3, at 545-576; and Joel Hellman et al., 'Measuring Governance, Corruption, and State Capture-How Firms and Bureaucrats Shape the Business Environment in Transition Economies', World Bank Working Paper 2312 (Washington, 2000).

${ }^{48}$ See Vladimir Popov, 'Lessons from Transition Economies - Strong Institutions Are More Important than the Speed of Reforms', Paper presented at the United Nations Research Institute for Social Development (UNRISD) meeting in Capetown on 7-8 September 2001 
quality legal advice, and where they are not able to do so, they have to admit it and send clients elsewhere; ${ }^{49}$ and they have to learn and apply general international/Western standards of professional ethics;

- administrators have to learn to serve their constituents and to facilitate legitimate commercial, social, cultural and personal life;

- legal education has to be reformed more rapidly to reflect not only the changes in legislation but also the (necessary) changes in legal culture, ${ }^{50}$

- the people in general have to learn to connect power and responsibility and to assert their rights via democratic and judicial mechanisms;

- and the media have to learn to fulfill their function in the game of checks and balances; serious investigative journalism has to develop and Western standards of research, evidence and ethics in a broader sense have to be adopted.

It is easy to see that the adoption of Western-style legislation and the organisation of training seminars for judges and administrators about these new laws alone are not going to be enough to achieve a fundamental administrative and court reform, or a real change in legal culture. ${ }^{51}$ Therefore, the next part of the analysis will deal with the question: what really needs to be done in Central and Eastern Europe to achieve the requisite administrative and court reform?

\section{The Pivotal Problem in Practice: Reforming the People}

The main hurdle on the way to achieving a fundamental change of legal culture - which is the crux of the matter-can be summarised in a single question: how to get the people to change?

One extreme approach was taken in the context of German re-unification. Within months of the former German Democratic Republic becoming part of the Federal Republic of Germany (FRG), 100\% of all judges and law professors and a very high percentage of all public prosecutors and high-level lawyers in the public administration lost their jobs and were replaced by Western-trained lawyers from the FRG. Similarly, most attorneys were disbarred and new attorneys from West Germany came in to take over the profession. This was justified because of their strong ideological identification with the former Communist régime, which had been a requirement for all high-level lawyers in the country. It was facilitated by the fact that East Germany essentially

49 Currently, employed lawyers in Estonian firms are being paid only on the basis of the actual sums billed to their clients. Thus, it happens regularly that an attorney will rather deal with a client him- or herself than sending the client to the colleague next door, even if the latter is much more specialised in the respective field.

${ }^{50}$ See, e.g. Jiri Zemanek, 'Legal Culture in the Czech Republic as Challenged by the Perspective of Accession to the European Union', in Jürgen Basedow et al., (eds), Private Law in the International ArenaFrom National Conflict Rules Towards Harmonization and Unification-Liber Amicorum Kurt Siehr (The Hague, 2000), at 863-874, in particular at 866 et seq.

51 The lack of a legal culture based on the rule of law is stressed by Open Society Institute (ed.), Monitoring the EU Accession Process: Judicial Independence, (Budapest, 2001): '[The] subordination of judges to politicians and of law to politics extended from mundane administration to matters at the core of judicial decision-making. The continuing effects of this history on public and political ideas about the judiciary, and on judges' views of their role, should not be underestimated' (at 21-22). For a very high quality comparative study see Erhard Blankenburg et al. (eds), 'Legal Culture in Five Central European Countries', WRR Scientific Council for Government Policy, Working Document W111 (The Hague, 2000). 
adopted the West German legal system, lock, stock and barrel. It was ultimately possible only because there was widespread under-employment among West German lawyers and many saw golden opportunities in the under-developed East. ${ }^{52}$

Literally the opposite approach was taken in the other Central and Eastern European Countries, where close to $100 \%{ }^{53}$ of all judges, attorneys, law professors and lawyers in the public administration kept their jobs, regardless of their ideological position in the old régimes. ${ }^{54}$ This was considered unavoidable, since there were simply no alternatives. There were no Western-trained lawyers waiting in the wings with the necessary knowledge of the local legal system - which largely stayed in place at first - the necessary knowledge of the language and the necessary knowledge of the specific legal culture. However, relying on the gradual replacement of retiring judges and administrators with young and better-trained recruits will obviously take an entire generation. ${ }^{55}$

It is almost ironic that both extremes have since led to similar problems of legitimacy and acceptance by the population at large, in one case because the lawyers are perceived as foreigners ${ }^{56}$ in the other because they are perceived as inefficient and corrupt.

As is often the case, the ideal would be in the middle. Ideally, the CEECs should retain those lawyers that performed their duties in a lawful and ethical manner under the old régimes and are willing and able to learn the new system, the new legislation, and most importantly, the new legal culture and the methodological skills it requires. At the same time, the CEECs should replace those lawyers that did not behave in a lawful and ethical way under the old régimes andlor are not willing or able to learn and to change. This is easier said than done, however. Finding out who misbehaved in the old system would probably have been possible. Yet, efforts undertaken to this end were rarely more than pro forma. Finding out who is willing and able to learn and to change, and on that basis to separate the wheat from the chaff, is a problem of yet another magnitude. There are no procedures, exams or lie detectors to render the correct answers to this question. Only their performance in practice, i.e. during the transition, can provide these answers, if it is properly evaluated. Given the additional problem that

${ }^{52}$ It is beyond the scope of the present paper to criticise the approach taken and results achieved in the context of German re-unification. For an economic analysis see, e.g. Horst Brezinski, "10 Years of German Unification-Success or Failure?', in Kari Liuhto (ed.), Ten Years of Economic Transformation, Vol. I, The Economies in Transition and the EU Enlargement (Lappeenranta, 2001), at 2-19.

${ }^{53}$ In Estonia, there were approximately 100 judges in 1980 and a similar number in 1990 . After independence, all judges had to be re-appointed by the President. Some did not even apply, since they knew that their involvement in the Soviet system would preclude them. Of those that did apply, $17 \%$ were refused. In total, 190 former judges and prosecutors were re-instated and appointed for life. See Erhard Blankenburg et al. (eds), 'Legal Culture in Five Central European Countries', WRR Scientific Council for Government Policy, Working Document W111 (The Hague, 2000), at 85. By contrast, in Poland, there was no screening whatsoever of public officials after the beginning of the reform process; only in 1997 a "lustration' statute was passed; ibid., at p. 99. In Hungary and the Czech Republic, the process was similar; ibid., at 123 , respectively at $156-157$.

${ }^{54}$ Until 2000, the Dean of the Law School of the University of Latvia was a professor of constitutional law, who had taught scientific Communism most of his life. In the meantime he has retired and was replaced by a young, German-trained assistant professor. While the latter is ideologically 'clean', motivated and talented, he had first to complete his doctoral dissertation.

${ }^{55}$ Or even more, since the (higher) (legal) education in CEECs has its own reform problems and even today does not necessarily provide candidates for the civil service who are fully comparable to their Western counterparts; see also below at V (B) (d).

${ }^{56}$ A popular proverb says that Germany used to have one people in two States, and now it has two peoples in one State. 
most judges and many administrators in CEECs have in the meantime been (re-)appointed for life and cannot (easily) be removed, the trick will be to get as many of them as possible to change. That will be the topic of the remaining chapter of this article.

\section{Practical Solutions: How to Achieve Administrative and Court Reform and How Not to}

\section{A The Predominant Types of Efforts Until 2001}

During the first decade of transformation, three types of efforts dominated the drive for administrative and court reform. First of all, a large number of legislative changes were made. New constitutions were adopted which included catalogues of human rights and fundamental freedoms, provided for the separation of the legislature, executive and judiciary, and guaranteed the independence of the judges. This was followed by the adoption of new legislation regulating the courts, the court procedures, enforcement of judgements and administrative decisions and the civil service in general.

Even though these new laws were the centrepieces of the official reform efforts, ${ }^{57}$ their practical impact was often limited. On the one hand, little or no attention - and certainly no significant resources - was given to the implementation of the new laws. On the other hand, many of these laws were subsequently amended so many times ${ }^{58}$ that even their publication could hardly keep up with the amendments, let alone the reception and acceptance by the affected audience. Not infrequently, significant changes made by one government were literally reversed after a new government had come to power. This phenomenon could be observed with a variety of laws but mostly with those connected with the exercise of official authority. It shows that the Soviet culture of using the public administration for political ends and sometimes even for personal advantage has still not been fully overcome.

The second main tool has been a variety of training efforts, particularly in the format of seminars and workshops for judges, prosecutors, administrators and private-sector lawyers. On one hand, these seminars were dedicated to the reformed national legislation. On the other hand, attempts were made to educate the legal profession about EU law. During the early years, the typical format of such seminars could be described as follows: some $30-50$ people were brought together in a lecture room and exposed to a full-day or even several full-days of frontal lectures delivered by one or two foreign 'experts' in a foreign language. With luck, the members of the audience were reasonably compatible in terms of their previous understanding of the subject and professional training needs. In exceptionally favourable circumstances, simultaneous interpretation was even provided. The lecturers usually spoke either about the fundamentals of EU law and policy making or about a topic of national law-their own national law, that is. The setting inevitably ended in frustration for both sides. The audience either did not understand much of what was said or at least did not see its

\footnotetext{
57 Verheijen finds that "[the] adoption of laws has so far been the main and sometimes the only administrative development tool' and concludes that "politicians seem to have misunderstood the term "Rule of Law" as "Rule by Law". See A. J. G. Verheijen, 'Administrative Capacity Development - A Race Against Time?', WRR Scientific Council for Government Policy, Working Document W107 (The Hague, 2000) at 42.

${ }^{58}$ For examples see Erhard Blankenburg et al. (eds), 'Legal Culture in Five Central European Countries', WRR Scientific Council for Government Policy, Working Document W111, (The Hague, 2000).
} 
relevance to their actual needs, in particular since questions about one or the other problem that they had already encountered in practice were inevitably answered along the lines 'Well, I don't know how it is in your country, but in my country this is what we do'. The lecturers also sensed the limited usefulness of their work but took consolation in the tourist components of their trip and the consultant's fee they each received.

In more recent times, the training has largely been taken over by people who are from or at least in the respective countries. This has made it easier to provide the lectures at more suitable times and in less intensive formats. However, it does not mean that all is well on the training front. A typical setting nowadays looks like this: somebody in the Ministry of Justice - or whoever gets to say how the respective allocations from the PHARE budget will be spent - decides that the judges/prosecutors/administrators have had enough general EU law and now need to learn about the customs code or some other highly specialised topic. ${ }^{59} \mathrm{~A}$ one- or two-day seminar is scheduled and again, 30-50 persons are brought together in a lecture room. With luck, the local instructor will really be an experienced lecturer and knowledgeable in the respective field. However, that is by no means guaranteed.$^{60}$ The audience will not have linguistic comprehension problems. However, the majority will not have had or will not remember much from the more general courses on EU law. In particular, it is virtually ensured that the majority has no concept of the most important and distinguishing features of EU law, that is its supremacy, direct effect and enforceability. Consequently, there will be a handful of truly interested persons in the room, who engage in discussions with the lecturer about problems of practical relevance connected to the topic. Then there will be a middle group, maybe one-third of the audience, trying to understand and learn - with limited success as the foundations are simply not there. Finally, the rest of the group will be drifting in and out of the room, receiving calls on their mobile phones, extending the coffee breaks and/or disappearing altogether in the afternoon.

The third major effort towards administrative and court reform can be summarised under the headline of twinning and similar cooperation programmes, i.e. bilateral cooperation between the government and/or administration of a Member State/Western State with the respective counterparts in a candidate State. There have not only been a large number of such partnerships but also a great diversity in them. ${ }^{61}$ Thus, it is clearly

${ }^{59}$ The distinction between more general, cross-sectoral topics and highly specific substantive topics has been labelled 'horizontal' versus 'vertical'. At the beginning of the transition process, the Commission promoted horizontal training. Later it shifted to vertical training. Most recently, however, it has realised that too much vertical training leads to a fragmentation of the public administration in CEECs and to narrowtrack specialisation. Thus, there is now a renewed emphasis on horizontal training, which should ideally put participants in a position to study the highly specific questions on their own when they come up in their work.

${ }^{60}$ It has happened more than once to the present author that the consortium where he participated in a bid for a training programme was told that their bid had clearly been the most sophisticated, with the bestqualified lecturers, but unfortunately too expensive. Later, one could see some young colleagues from the administrative unit in question do the training themselves, sometimes actually using the curriculum of the first consortium, and throwing in a bit of theoretical knowledge from their recently completed studies for good measure.

${ }^{61}$ A number of EU and non-EU programmes are described by Gerhard Eisl, 'Relations with the Central and Eastern European Countries in Justice and Home Affairs: Deficits and Options', European Foreign Affairs Review 1997, at 351-366. 
beyond the scope of the present article to attempt a comprehensive evaluation. Nevertheless, a couple of remarks shall be made. In general, it is an excellent idea to bring together customs officers with customs officers, bailiffs with bailiffs, criminal judges with criminal judges, as they have similar problems to solve and can share their experiences. However, most of the programmes have suffered from the fact that not enough people were able to visit the twinning partners and those who did go were not able to stay long enough. Short visits, often just a couple of days, ${ }^{62}$ are usually not enough to overcome language barriers and differences in legal systems in order to create a bond that truly allows a fruitful and lasting exchange of experience. A notable exception is the Central European and Eurasian Law Initiative (CEELI) of the American Bar Association, which has been bringing qualified American lawyers to partner-countries for periods of several months to several years. ${ }^{63}$ Another good result of a number of these bilateral cooperation programmes has been the technical support for administrations and courts in the partner-countries. A lot of IT and other office equipment and books, for example, has been supplied and installed on that basis.

The main criticism of the reform efforts undertaken in the first decade, however, concerns the lack of an overall strategy. Whether one looks at the EU Commission's Agenda 2000 or its progress reports up to the year 2000 , or whether one looks at the National Programmes for the Adoption of the Acquis (NPAAs) for the same period, the language about administrative and court reform is vague, the goals are kept general and hardly any specific measures are proposed or announced. ${ }^{64}$ It seems fair to say that the problem of changing the legal and administrative culture in CEECs has been seriously underestimated by both sides.

Most recently, however, the Commission has changed its approach and has adopted a stronger focus on administrative and court reform and more concrete proposals for the CEECs, as well as additional financial support. This was launched by the Report of the European Commission on the Progress Towards Accession by Each of the Candidate Countries: Making a Success of Enlargement, ${ }^{65}$ which announces an Action Plan for Administrative and Judicial Capacity' (the 'Strategy Paper'). The 'Action Plan' itself was recently adopted. ${ }^{66}$ The measures promoted in these documents and a number of additional or alternative ideas will be introduced in the next section.

${ }^{62}$ See, e.g. the various projects of the Deutsche Stiftung für internationale rechtliche Zusammenarbeit, the main agent of the German government for the promotion of administrative and court reform in CEECs, at http://www.irz.de/bj98_01.htm.

${ }^{63}$ CEELI legal positions and fellowships are advertised at http://ists.partners-iutl.net/pipermail/opportunities/2003-March/002045.html, last accessed 28 April 2003.

${ }_{64}$ The Estonian NPAA for 2001, for example, explained that 2000 was the year for discussion about public administration reform and that 2001 should become the year for a 'shift toward more action-oriented solutions'. For that purpose, the 'Draft Public Administration Reform Programme' prepared in 1999 was intended for approval by the government during the year 2001 (State Chancellery, Office of European Integration, NPAA 2001, Tallinn, 2001, at 7). When reading this, one does not exactly feel a sense of urgency on behalf of the Estonian government.

${ }^{65}$ European Commission (ed.), Making a Success of Enlargement-Strategy Paper and Report on the Progress Towards Accession by each of the Candidate Countries, (Brussels, 13 November 2001). See also the Accession Partnership documents for each of the candidate countries, as last revised in January 2002, OJ 2002 L44, available at http://europa.eu.int/eur-lex/en/archive/2002/1_04420020214en.html, last accessed 28 April 2003.

${ }^{66}$ Communication from the Commission on the Action Plan for Administrative and Judicial Capacity, and the Monitoring of Commitments Made by the Negotiating Countries in the Accession Negotiations, Com (2002) 256 final, Brussels 5 June 2002. 


\section{$B \quad$ New Directions and Additional Suggestions}

\section{a) Stronger Focus on Suitable Framework Legislation}

Wherever this has still not been achieved, the necessary framework legislation has to be adopted and, once in place, has to be implemented in full. Furthermore, these laws have to be insulated from political interference and from frequent change for political reasons. ${ }^{67}$ This concerns in particular the creation of efficient legislation for:

- the structure of the courts;

- the court procedure in civil, administrative, and criminal cases;

- the status, rights and duties of judges and public prosecutors, as well as bailiffs and court assistants;

- the structure and division of competences in the public administration;

- the status, rights and duties of civil servants in general;

- the establishment, structure and procedure of supporting units such as land registers, company registers, etc.

\section{b) More Conscious Improvement of Administrative and Court Structures}

While the adoption of the necessary legislation is relatively easy and inexpensive, the creation of adequate structures is difficult, can only be implemented gradually and requires the allocation of significant financial and other resources at all levels; including the ministries, central administration, courts, as well as regional and local administrations. One legacy of Soviet/communist times is a very top-heavy administration, where decision-making and control were literally monopolised by the respective ministries. Since this phenomenon can still be perceived throughout the CEECs, there have to be more conscious and more specific efforts at devolution of decision-making authority and responsibility to lower units of administration, and at decentralisation of powers to regional and local entities. However, given the widespread hesitations among civil servants to take decisions themselves rather than asking for instruction from above and thus safety against making mistakes, ${ }^{68}$ such devolution and decentralisation has to go hand in hand with the creation of adequate control mechanisms, as well as training.

Independent and specialised administrative courts are not yet evident in some of the candidate countries. In general, the protection of individual rights against the state is an underdeveloped area of law, which again is explained by the previous dictatorial régimes. Therefore, the EU and the Western twinning partners should place specific emphasis on this area, develop model administrative procedural codes and model administrative court statutes and send Western experts for extended internships to help with the setting-up of the necessary structures. Coaching, as a specific form of twinning, should also be more extensively used.

Another element of proper supervisory structures, which is underestimated in at least some of the CEECs, is the ombudsman office. A high-profile ombudsman, with

${ }^{67}$ Verheijen has detected many problems in this respect, see A. J. G. Verheijen, 'Administrative Capacity Development-A Race Against Time?', WRR Scientific Council for Government Policy, Working Document W107 (The Hague, 2000), at 26 et seq.

${ }^{68}$ The positive effects of growing personal self-confidence among civil servants and the contribution of more and more younger people who have not experienced the old style are, unfortunately, at least partially offset by the growing professional insecurity in the face of vast numbers of new - and rapidly evolving - laws, and the unfamiliar requirements imposed by EU and international law. 
competence to hear complaints against all kinds of abusive or illegal behaviour by administrative officers, with the necessary resources to deal with growing numbers of such complaints, and with adequate instruments to achieve satisfaction for the complainants, ${ }^{69}$ where justified, can be a powerful agent of change for administrative structures. Last but not least, the parliaments, currently inundated with legislative procedures for the implementation of the acquis communautaire, have to take their function as the principal controllers of the executive more seriously and have to be equipped and trained to do so.

The administrations (and legislative drafting offices) also have to learn to do an integrated impact assessment prior to the adoption of each important measure. If serious analysis is not undertaken of the potential impact of a measure - e.g. on the environment, consumers, social partners, the economy in general, international trade, the state budget - as well as its compatibility with existing national and EU law, the countries may move one step forward and slide two steps backward at the same time. In particular in candidate countries where the responsibility for the implementation of the acquis was divided between various ministries (such as Latvia, until recently), there are many examples of mutually incompatible national measures and sometimes even mutually incompatible administrative structures. Another step to be taken, therefore, is to develop functioning inter-ministerial working groups. Again, the EU should provide guidelines and models for these procedures. The improvement of the administrative capacity will also require a strengthening of the statistical capacity in the candidate countries. Specifically with respect to the courts, the EU should promote a complete separation of the courts from the ministries of justice or other parts of the executive. ${ }^{70}$ In Soviet times, it was common practice to put pressure on judges and courts that were considered overly independent, by, for example, inundating them with work and then disciplining them for not being able to keep up with it or by starving them out as far as financial and other resources were concerned. In light of this legacy, it seems to be strongly advisable to create self-governing systems for the courts. Such national judicial councils - or whatever they might be called - should be composed of representatives of the judiciary and should have sole authority to decide all questions of internal administration, budgetary implementation, as well as issues related to the individual careers of judges, including disciplinary measures. ${ }^{71}$ These self-governing bodies should also be the ones who determine training needs of judges and court staff and develop multi-annual programmes to meet these needs.

${ }^{69}$ Again, the EU, World Bank or other interested parties could develop model statutes for such ombudsman offices. Otherwise there is a risk of formal satisfaction of the idea together with functional sabotage. For example, the Estonian ombudsman is at the same time the Legal Chancellor, with competence to supervise the legality of parliamentary and administrative acts. The fact that he also hears private complaints is little known and whether or not complaints to him have suspensory effect on deadlines for court applications is unclear.

${ }^{70}$ In Estonia, for example, only the Supreme Court is independent from the Ministry of Justice, with its own budget and administrative autonomy. The other courts are supervised by the ministry and the ministry takes decisions on their behalf on issues such as training programmes, budgetary allocations, acquisition of equipment, promotion of judges, disciplinary questions, etc. See Erhard Blankenburg et al. (eds), 'Legal Culture in Five Central European Countries', WRR Scientific Council for Government Policy, Working Document W111 (The Hague, 2000), at 86-87.

${ }^{71}$ See, e.g. Open Society Institute (ed.), Monitoring the EU Accession Process: Judicial Independence (Budapest, 2001), at 23 and 25. 
Last, but not least, it may be a good idea to link the number of positions in the judiciary to the increasing caseload. This could protect the courts against unmanageable workloads, which would inevitably lead to excessive stress and low morale among the judges, a lowering of the quality of the decisions and public criticism for unacceptably lengthy proceedings.

\section{c) More Efficient Training Programmes for Judges and Civil Servants}

Even though large amounts of resources have been spent on training, this area has been riddled with problems, some of which have been described above. The real impact of thousands of seminars, workshops and lectures has been disappointing. The reasons are manifold, having at their centre the lack of an overall strategy. In order to get better results from training in the next couple of years, a number of principles should be adopted. First and foremost, the target groups of training efforts should be involved in the determination of training needs and in the design of curricula and events. Second, integrated and structured multi-annual training plans need to be developed. Third, performance and progress measurement schemes have to be introduced at the institutional and at the personal level. For example, a person should only move on to an advanced training programme after the successful completion of a foundational programme has been verified by means of an examination. Fourth, incentive systems must be created for judges and civil servants to take part in training programmes and to take them seriously. In this context, a carrot-and-stick approach is recommended. Even if judges and civil servants are appointed for life, there are many forms of incentives, ranging from financial bonuses and material advantages, such as priority allocation of modern IT equipment or renovated offices, to opportunities for participation in twinning programmes and international conferences, that can be used to motivate people to take part in training schemes and to study for exams. Given the legacy of harassment of rebellious judges and civil servants in Soviet times, it is surprising that the present-day administrations do not seem to have nearly as much imagination about positive incentives. Often, a mere reversal of old-style techniques would do just fine.

Another problem to be discussed in this context is brain drain. Already, public administrations in CEECs suffer from a very high turnover, as many qualified persons are leaving for better-paid positions in the private sector, after having obtained workexperience and on-the-job training from the state. Further improvement of working conditions and remuneration, to be discussed below, is one way of reducing the problem. However, it is clear that EU accession itself will cause a significant brain drain, as significant numbers of the best qualified administrators will leave for-comparatively - very well-paid positions in Brussels. Since the public sector in CEECs will not be able to compete with the West for a long time, as far as salaries and working conditions are concerned, the only sensible response is essentially to train two to three people for every person that is actually needed in the long term.

\section{d) General Reform of (Higher) (Legal) Education}

The need for extensive training inside the public administration will continue to exist for many years to come. However, unless reform of the educational sector in CEECs is taken more seriously, the needs will grow rather than dwindle. The experience at Concordia International University Estonia, which has provided Western-style education in business, law, media and public relations, as well as political science, for a number of years to students from all three Baltic States, clearly shows that the entry-level of freshmen has not improved - with the sole exception of their knowledge of English. 
The schools and high schools in CEECs have generally been neglected in the transition process so far and schoolteachers are usually amongst the most poorly paid civil servants with income levels often below $€ 500$ per month. Furthermore, even inside the institutions of higher education, reform has been slow. Old-style frontal lectures, learning by rote and multiple-choice exams are still widespread. At the same time, there is little or no emphasis on independent problem-solving skills and other professional skills, such as legal argumentation and legal writing. ${ }^{72}$

\section{e) More Competitive, Transparent, and Meritocratic Human \\ Resource Management}

In general, there are no strong and independent public administrations in CEECs. The structures are top-heavy and very much dependent on short-term political preferences, sometimes even the personal preferences of certain politicians. Multi-annual institutional human resource development plans are still not commonly available in CEECs. Therefore, career perspectives, professional development opportunities and the allocation of resources for human resource management have been subject to uncertainty and political interference. In order to change the institutional culture, it will be necessary to create modern rules about hiring and promotion in the public service, with open competition for positions, and appeals procedures. Clear performance standards have to be drawn up for each administrative position as a basis for meritocratic promotion systems. Independence has to be complemented with accountability of the administrative institutions and of each executive unit within them. In this way, the staff has to be reassured of their powers and rights, and also has to be made more aware of their responsibilities and the possible consequences of not fulfilling them. Model codes, best practice guidelines, benchmarking, ethics codes, operational guidelines and manuals, as well as support in training are some of the examples how the EU and other Western partners can support the CEECs in these efforts.

\section{f) Further Improvement of Working Conditions}

The Central European States that are currently negotiating for membership in the EU have already made relatively good progress in the improvement of working conditions and salaries for judges and civil servants. In Estonia, the salary of a judge is now amongst the highest in the entire civil service and about four times the national average. There is a legal link between the salaries of the judges and of the ministers, i.e. increases for ministers means increases for judges. The salary of the Chief Justice of the Supreme Court corresponds to that of the Prime Minister. ${ }^{73}$ Thus, it can be said that Estonia ${ }^{74}$ fulfills the international standards, according to which the status and remuneration of judges [should be] commensurate with the dignity of their profession and burden of responsibilities' ${ }^{75}$ and has to be 'sufficient . . . to secure true economic

${ }^{72}$ See generally Richard H. Jones, 'Educating for an Open Society-Higher Education Reform in Central and Eastern Europe as a Catalyst for the Emergence of a Sustainable Democratic Market Economy', WRR Scientific Council for Government Policy, Working Document W108 (The Hague, 2000).

${ }^{73}$ See Erhard Blankenburg et al. (eds), 'Legal Culture in Five Central European Countries', WRR Scientific Council for Government Policy, Working Document W111 (The Hague, 2000) at 85.

${ }^{74}$ For information on the other candidate countries see Open Society Institute (ed.), Monitoring the EU Accession Process: Judicial Independence (Budapest, 2001) at 49-50.

${ }^{75}$ See Principle III.1.b. of the Council of Europe Recommendation No. R (94) 12 of the Committee of Ministers to Member States on the Independence, Efficiency and Role of Judges of 13 October 1994. See also the Basic Principles on the Independence of the Judiciary adopted at the Seventh United Nations 
independence. ${ }^{76}$ As far as other positions in the civil service are concerned, the situation is often not as good, which mainly causes difficulties in the recruitment of highly qualified university graduates.

The situation with respect to physical working conditions varies widely. Usually, the offices of civil servants in the ministries and other central administrative units have already been renovated and are in reasonably decent condition. Not infrequently, they are located in attractive city-centre locations, which can be a fringe benefit to attract good-quality staff. In the meantime, IT equipment has also been widely brought up to Western standards in these administrative units. The picture is generally less positive in regional and local administrative units. Significant weaknesses prevail throughout when it comes to adequate support staff, for example for non-judicial work at the courts, as well as libraries and documentation centres that meet the needs of modern administrations and courts, having to deal with EU and international law on a regular basis. The latter problem can be somewhat compensated by access to the Internet, which is usually provided. However, training on international legal research has not been systematically given in any of the candidate States.

\section{g) Systematic Promotion of Good Governance, Professional Ethics and Personal Integrity}

In Soviet-times it was everyday practice to bring a small present or to offer money when requesting any kind of service from civil servants, including employees at hospitals, schools and most administrative agencies. The presents might have been a cake, some flowers, vegetables from the garden, a box of chocolates or some goods that were in short supply. In this way, the applicants sought to obtain the officials' favour, since they were largely at their mercy and had little or no possibilities of complaining against inaction or illegal rejections. The system also acknowledged the low level of income of the civil servants who were not infrequently dependent upon the presents. This culture is still strongly entrenched today ${ }^{77}$ and while it is not necessarily corruption in the narrow sense ${ }^{78}$ it is clearly a problem and is counter-productive for high standards of professionalism and for the execution of duties according to the rule of law. In modern times, corruption proper has been added to the routine experience of regular citizens in their contacts with public officials, i.e. the demand for illegal payments to avert negative consequences or to promote positive action by the administration. One of many explanations for the proliferation of corrupt practices has again been the relatively low salary of many civil servants, making it difficult for them to participate in the new economic freedoms, such as the purchase of imported goods and tourist travel abroad. One may ask, therefore, whether this is not just a temporary phenomenon that will take care of

Congress on the Prevention of Crime and the Treatment of Offenders, Milan 26 August to 2 September 1985, UN Doc. A/CONF.121/22/Rev.1 at 59 (1985).

${ }^{76}$ See Article 13 of the Universal Charter of the Judge, General Council of the International Association of Judges (ed.), Universal Charter of the Judge (Taipei, 1999).

${ }^{77}$ See William L. Miller, Ase B. Grodeland, and Tatyana Y. Koshechkina, Are the People Victims or Accomplices? The Use of Presents and Bribes to Influence Officials in Eastern Europe (Budapest, 1998).

${ }^{78}$ Schacter and Shah have defined three types of corrupt practices: a) bureaucratic or 'petty' corruption, where a large number of public officials abuses their public office to take small bribes or favours; $b$ ) 'grand corruption', where a relatively small number of public officials abuses public office to extract or steal vast amounts of money; and c) 'state capture' or 'regulatory capture', where public and private agents collude for private benefit. See Mark Schacter and Anwar Shah, Anti-Corruption Programs: Look Before You Leap (Seoul, 2000). 
itself, as salaries and living conditions are improving. However, as a World Bank study has demonstrated, the improvement of salaries and employment conditions per se does not bring down the level of corruption and nepotism. ${ }^{79}$ Therefore, separate and specific efforts have to be undertaken in order to promote good governance, professional ethics and personal integrity.

At the outset of such efforts there has to be a clear and unambiguous definition of what constitutes corrupt practice. ${ }^{80}$ To this end, ethics codes have to be adopted for the different professions ${ }^{81}$ which define, inter alia, the kind of presents that can be accepted by a civil servant, those that can be accepted but need to be notified and surrendered to the administration, and those that have to be rejected. Second, complaint mechanisms have to be established that citizens can resort to if they have been harassed for bribes. ${ }^{82}$ Ombudsman offices can be used for this purpose, if they are sufficiently accessible throughout the country and if they have the capacity to investigate cases when necessary in order to protect civil servants against blackmail. Third, clear and effective sanctions have to be created both for civil servants asking for illegal bribes and for citizens offering them. ${ }^{83}$ Last, but not least, the new rules and mechanisms have to be made publicly known ${ }^{84}$ in the context of a public relations campaign ${ }^{85}$ promoting clean and transparent government, where all decisions are taken on the basis of the rule of law and where favouritism and discriminatory practices have no place.

\section{h) Innovative Approaches to Quality Control and Performance Measurement}

In recent years a number of innovative suggestions have been made to measure and improve the performance of the public administration. Some of the ideas have been borrowed from private-sector developments in management, such as SWOT analysis exercises ${ }^{86}$ or Total Quality Management (TQM). ${ }^{87}$ Others have already been in use for

79 See Vinod Thomas et al., The Quality of Growth, (Washington, 2000), at p. 152; also available at http://www-wds.worldbank.org/servlet/WDS_IBank_Servlet?pcont= details\&eid=000094946_00092205320345.

${ }^{80}$ Another issue in this context is the widespread use of employer's resources and time for private purposes in CEECs. Since everything used to belong to the State, which did not exactly treat its people with great care and attention, there is a deeply entrenched attitude that takes it for granted that office phones are used for personal calls, office supplies are taken home, and trips to the doctor or the supermarket are undertaken during working hours.

${ }^{81}$ See, e.g. Barbara Kudrycka, Ethical Codes of Polish Public Officials (Budapest, 1999).

${ }^{82}$ See Jeff Huther and Anwar Shah, Anti-Corruption Policies and Programs: a Framework for Evaluation (Washington, 2000).

83 According to Huther and Shah, the expected costs of undertaking a corrupt act must clearly exceed the expected gains, ibid., at 2 .

${ }^{84}$ To give a small example: when arriving at Nairobi's Jomo Kenyatta airport, travellers have to pass immigration. In the respective hall, there are very clearly visible signs in many languages informing them that there is no fee for the immigration formalities and that every person is entitled to rapid and courteous service. Clear information about the rights of citizens and the duties of civil servants, including any fees that are to be charged, can effectively reduce opportunities for extortion of bribes.

${ }^{85}$ See, e.g. Rick Stapenhurst, 'The Media's Role in Curbing Corruption', World Bank Institute Working Paper 21024 (Washington, 2000), available at http://www-wds.worldbank.org/servlet/WDS_IBank_Servlet?pcont=details\&eid=000094946_00101305481312.

${ }^{86}$ SWOT stands for 'Strengths, Weaknesses, Opportunities, Threats' and describes a structured self-analysis exercise with different stakeholders in an institution.

${ }^{87}$ See SIGMA Paper no. 4, 'Management Control in Modern Government Administration: Some Comparative Practices' (Paris, 1996). 
some time in certain sectors of the public administration and are now being more generally applied, such as the sharing of best practice codes and standards ${ }^{88}$ benchmarking methods, peer reviews, external audits, accreditations and the like.

In the context of administrative capacity building for EU membership, monitoring by the EU Commission has to be mentioned. As part of the pre-accession programme, the Commission has been monitoring the progress of the candidate countries with a variety of means, including self-evaluation reports, investigations by the Commission delegations in the candidate countries and peer-review procedures. The results were not only reflected in general terms in the annual progress reports but were also used to finetune the collaboration and support under the Accession Partnership. For the majority of the candidate States, the progress report of 2002 is the last one before signature of the Accession Treaty. Nevertheless, the Commission has already announced that it will continue to operate the pre-accession support programmes in the year 2003 and, most likely, beyond actual accession. It also wants to continue the monitoring procedures at least up to the day of accession. ${ }^{89}$ However, any monitoring exercises will already change in character in 2003, since the 'successful' candidate countries will be less susceptible to pressure from the Commission. Finally, at the date of accession, they will become fully equal Member States, subject only to the procedures foreseen under Article $226 \mathrm{EC}$ and - in extreme cases - Article 7 TEU. ${ }^{90}$

In the literature, there have been proposals for imposing post-accession transitional periods of monitoring the new Member States via the accession treaties, which would have to be combined with more extensive control and enforcement instruments for the Commission. ${ }^{91}$ Withholding of structural funds or agricultural support could be effective means of putting pressure on the new Member States, since all of them would be net recipients of EU funds. However, the EU has to be careful not to apply double standards. Already, the requirements for the candidate countries have become much stricter than ever before. If post-accession supervision beyond the existing instruments is introduced, it should apply to all Member States and not only those from Central and Eastern Europe. As the track record of the old Member States in the context of the Article 226 procedures shows, they also have their share of problems with the proper application of EU law.

In parallel to 'internal' supervisory mechanisms, public scrutiny as a means of quality control should generally be promoted more seriously. With respect to administrative action, citizens should be made aware of their rights in general, for example via a public relations campaign introducing a Charter of Citizens' Rights in administrative procedures. Public information offices should be established where citizens can receive advice

${ }^{88}$ Many terms have been used for this practice, including the development of operational guidelines and manuals, checklists, baseline criteria, etc. The most active institution for the promotion of administrative and court reform in CEECs by means of best practice codes and standards has been SIGMA, an initiative of the OECD, partly funded by the EU. See, e.g. SIGMA Paper no. 5, 'Civil Service Legislation Contents Checklist', (Paris, 1996); or SIGMA Paper no. 15, 'Check List on Law Drafting and Regulatory Management in Central and Eastern Europe', (Paris, 1999); or SIGMA Paper no. 27, 'European Principles for Public Administration', (Paris 1999).

89 See European Commission (ed.), Making a Success of Enlargement-Strategy Paper and Report on the Progress Towards Accession by each of the Candidate Countries, (Brussels, 13 November 2001), at 25.

${ }^{90}$ The so-called Francovich liability of the Member States for breaches of EU law must not be forgotten in this context, even though it does not belong to the monitoring powers of the EU and its Commission.

91 See A. J. G. Verheijen, 'Administrative Capacity Development-A Race Against Time?', WRR Scientific Council for Government Policy, Working Document W107 (The Hague, 2000) at 54. 
about their rights and obligations in dealing with the administration. Industry awareness campaigns and (subsidised) training for private-sector attorneys and counsellors are other possibilities with which to generate public demand for reform and good governance.

Individual administrative acts should be accompanied by clear and precise information about available legal remedies, at least when they are in written form. Similarly, with respect to court decisions, there should be a legal requirement that clear and comprehensive reasons be provided to the applicant/addressee, as well as information about available appeal procedures and how, where and when these can be initiated.

A particular mechanism of administrative self-control has worked very well in certain other countries. In German administrative law, complaints against a specific administrative act - or against administrative inaction in a specific case - have to be directed first against the administrative agency that acted or should have acted. This agency then has to write a justification for its action and send the complaint and its answer to the next-highest administrative authority for decision. The higher authority can reject the complaint by a motivated decision or instruct the lower authority to change its conduct. If the complainant is not satisfied with the result of the procedure, he or she can take the matter to the administrative court. Procedures brought directly to the administrative court are normally inadmissible. Since the administration has relatively short deadlines for responding to the complaint, the additional loss of time for the citizen is small. Also, the citizen is protected during that time, because the complaint has a 'suspensive' effect for the act in question. This so-called Widerspruchsverfahren is not only a very useful self-control mechanism for the administration, as it forces the acting authority to reconsider its decisions; it also provides the citizen with a first review which may either change the act to suit the complainant or provide a satisfactory motivation for the complainant to accept the 'unchanged' act. Thus, it also relieves the courts of considerable numbers of cases. CEECs that do not yet know such a procedure would be well-advised to consider its introduction.

Last but not least, critical academic discussion of case law and regulatory action should be encouraged. This important feedback mechanism for the courts and the administration is still completely underdeveloped in CEECs. Instead, there is a predominant attitude of hostility against criticism from any direction ${ }^{92}$ and public debate is obstructed by restricted access to judgements and related documents. ${ }^{93}$ Furthermore, as many CEECs are small, they have had only one dominant law school in the past ${ }^{94}$ and there is little or no inter-institutional debate in academia with the effect of developing different schools of thought about a certain legal issue. Some of the measures

${ }^{92}$ The Open Society Institute study goes as far as concluding that in some candidate States the judges seem to consider 'criticism from any quarter [as] an infringement on their independence'; see Open Society Institute (ed.), Monitoring the EU Accession Process: Judicial Independence (Budapest, 2001), at 20.

${ }^{93}$ In Estonia, only the judgments of the Supreme Court have been widely available for several years, including availability on the Internet. The appellate courts started only recently to make their judgements publicly available and access to the judgements of the first instance courts is still restricted to the parties and members of the judiciary. As a consequence, law students are not accustomed to working with case law other than that of the Supreme Court, and there is no systematic academic debate of the court practice, let alone critical publications, such as article-by-article commentaries, about the interpretation of the law by the courts.

94 Examples would be the University of Tartu School of Law in Estonia, the University of Latvia School of Law in Riga, Vilnius University School of Law in Lithuania, as well as Charles University School of Law in Prague. 
that could be taken to change this situation include the promotion of academic journals and publications on case law, article-by-article commentaries on important pieces of legislation, as well as the organisation of more regional contacts between academics from small countries. The ECSA network could play a role in the promotion of more academic exchange and more (critical) academic publications. In this context it was a grave mistake to organise the Erasmus exchange programmes in the usual hub-andspine fashion, where bilateral partnerships always had to include one academic institution of a Member State; partnerships between two institutions in candidate countries usually were not eligible for funding.

\section{i) Additional Ideas}

For reasons of time and space, it is quite impossible to attempt to compile a complete list of additional ideas that have already been discussed and/or tried out in one or the other geographic or topical context. Therefore, only some initiatives for court reform that have already been successfully used in order to deal with increasing workloads shall briefly be mentioned.

Special small claims courts with simplified rules of procedure have been successfully used for the improvement of consumer protection, for example in Portugal. Legal clinics at universities can provide practical training to students and improved access to justice for low-income and other vulnerable groups. Special conciliation courts are useful in cases where applicant and defendant will have to maintain certain contacts after the litigation, for example in landlord-tenant or neighbourhood disputes. Private arbitration courts do not have to be limited to large commercial litigation but can also serve useful purposes in regular civil litigation. This applies where the parties are willing to pay more in order to get a rapid and confidential judgement. Naturally, enforcement possibilities have to be on a par with those of state courts. Finally, inside the existing state courts, special units - pilot courts - can be created with mandates to experiment with changes in procedural rules, e-Europe projects, and other ideas for better caseflow management and overall better utilisation of resources. ${ }^{95}$

In general, these kinds of ideas have not received much attention in CEECs so far.

\section{Concluding Remarks}

Administrative and court reform was not very successful during the first decade of transition. Much time and money was invested with disappointing results overall. However, there are reasons for hoping that the investment was not altogether lost. Both the EU and the candidate countries have gained considerable experience in how and how not to promote this reform effectively. By now, better schemes and projects have been launched and many additional ideas are under consideration. Administrative and court reform is finally getting the priority attention it needs. This new focus is coming late. Too late to complete the reforms - or even just the main efforts - in time for accession in 2004. Thus, both the EU and the candidate countries have to commit themselves to large-scale and persistent reform efforts for many years to come. Finally, many of the old Member States would be well-advised to look critically at their own administrations and courts and to consider the experiences gained in Central and Eastern Europe.

95 For discussion of these and similar ideas see Russel B. Sunshine, 'Technical Assistance for Law Reform: Co-operative Strategies for Enhancing Quality and Impact', (2000) 2 European Journal of Law Reform, 1 , at 61-93; and Maria Dakolias and Javier Said, 'Judicial Reform: A Process of Change Through Pilot Courts', (2000) 2 European Journal of Law Reform, 1, at 95-117. 